\title{
Diversity and Abundance of Bee Flower Visitors of Beans in Borabu Sub-County, Western Kenya
}

\author{
Nyanumba N. Lilian ${ }^{1, a^{*}}$, Karanja N. Rebecca ${ }^{2, b}$, Gikungu Mary ${ }^{3, c}$ \\ ${ }^{1}$ Department of Botany Jomo Kenyatta University of Agriculture and Technology, P.O. Box 62000 \\ Nairobi, Kenya \\ ${ }^{2}$ Department of Plant Science, Kenyatta University, P. O. Box Nairobi, Kenya;
}

${ }^{3}$ National Museum of Kenya, P. O. Box 62000 Nairobi, Kenya

a*Email; nyanchamalilian8@gmail.com, Tel; +254715843626,

bEmail; rebeccakaranja2@gmail.com, Tel: +254722601849;

'Email; mgikungu@yahoo.com, Tel: 254721791373

\section{Keywords: Diversity, Abundance, Pollination, Apis, Nyansiongo}

\begin{abstract}
Globally bees form the main animal pollinators of most crops. Most agricultural crops rely on pollinators, particularly bees for pollination services. Declining of bee colonies due to anthropogenic factors has led to declines in food production in the world. Yet little is known about crop pollination in African countries. In Kenya pollination studies are still scanty, lack harmonisation and only a few crops have been studied. It is against this background that the study was chosen. One administrative sub location was purposively selected. Three plots were selected at equal $1 \mathrm{~km}$ distance along atransect laid in that sub location. Sampling of 3 plots each of $100 \mathrm{~m}$ x $100 \mathrm{~m}$ was established along transects. Bee sampling was done for 3 months using a sweep net and a bowl trap to collect bees. Diversity was computed using Shannon's diversity index while abundance was recorded using abundance curves. A total of 992 bee visitors from 2 families and 9 species were collected from the three study farms. High diversity and abundance of bees was recorded. Therefore, farmers, extension workers and other stakeholders should be sensitized and trained on the importance of bee pollination and its contribution to their welfare and on utilization of cost-effective strategies for bee conservation.
\end{abstract}

\subsection{Introduction}

Pollination is the process of sexual reproduction in plants, in which the male sexual cell, the pollen grain (a group of cells called gametophyte) is transferred to a female flower of the same species, germinates on receptive stigma and subsequently fertilizes the female gametophyte (ovule). Flowering plants require pollination to produce seed or fruit. Some plants are wind pollinated and others are self-pollinated, but many plant species require animal mediated cross pollination [17].

Studies have shown that plant community composition, pollination syndromes and pollinator types have not been well documented in Africa as compared to other regions in the world [4]. Data shows that Kenyan pollinators in crop productivity are still lacking for most crops [8].

The ecological interactions between plants and pollinators make important contributions to global diversity. Studies by [5] show that nested architecture; plant-pollinator networks reduce competition and increase biodiversity.

Pollinators increases food security and contributes to the improvement of livelihoods and increase of income of some of the world's poorest people found mainly in the Sub-Saharan Africa including Uganda [16]. Much as pollinators (bees) are known to pollinate most of the world's wild plant species and provide economically valuable pollination services to crops [13], their knowledge of strategies for conservation biology lags far behind other beneficial taxa such as parasitoids and predators [13]. However, pollinators are among biota's that are very sensitive to disturbance; particularly to anthropogenic activities (that is Pesticides use, habitat destruction and loss and grazing intensity) and to Intensification in land use systems and to change in farming practices [18]. Bees are important plant pollinators and any decline in numbers or species due to anthropogenic disturbances constitutes 
a significant threat both to biological diversity and their ecosystem services and to whole agricultural economics [14].

Bees complement each other in pollination. A more diverse bee community provides better pollination service especially in areas where mixed cropping is done, as different pollinators target different flowers. Diversity can help to reduce the risk that may arise due to lack of a pollinator during the critical period of crop flowering. For example, A. mellifera are known to abandon flower patches for more suitable ones and in such case, having other bee species can help counteract the lost honeybee function although this also depends on other crop requirements [8].

\subsection{Materials and Methods}

\subsection{Description of the study area}

Nyansiongo Sub-location is part of Borabu Sub County in the larger Nyamira County. It is one of the 14 sub-locations found in Borabu. It is situated at the border of Kisii-Sotik, about $40 \mathrm{~km}$ south east from Kisii town. According to the [7] this region is less populated compared to other sub-locations and covers an area of 3000 ha with the population of 35,413.The area has rich agricultural soils and receives plenty of rain which is well distributed throughout the year. In the months of JanuaryFebruary dry periods are experienced. More rain is experienced in the month of April with more than $1500 \mathrm{~mm}$. Soil type in this area is reddish brown and silt clay. The area consists of a rolling landscape with an altitude of 1850-1950m above sea-level but with some steep conical hills whose tops can have an altitude of $2060 \mathrm{~m}$ above sea level. Nyansiongo is known for its richness of flora. It consists of both tea as the main cash crop and indigenous trees like acacia and food crops such as bananas, maize, beans and sweet potatoes.

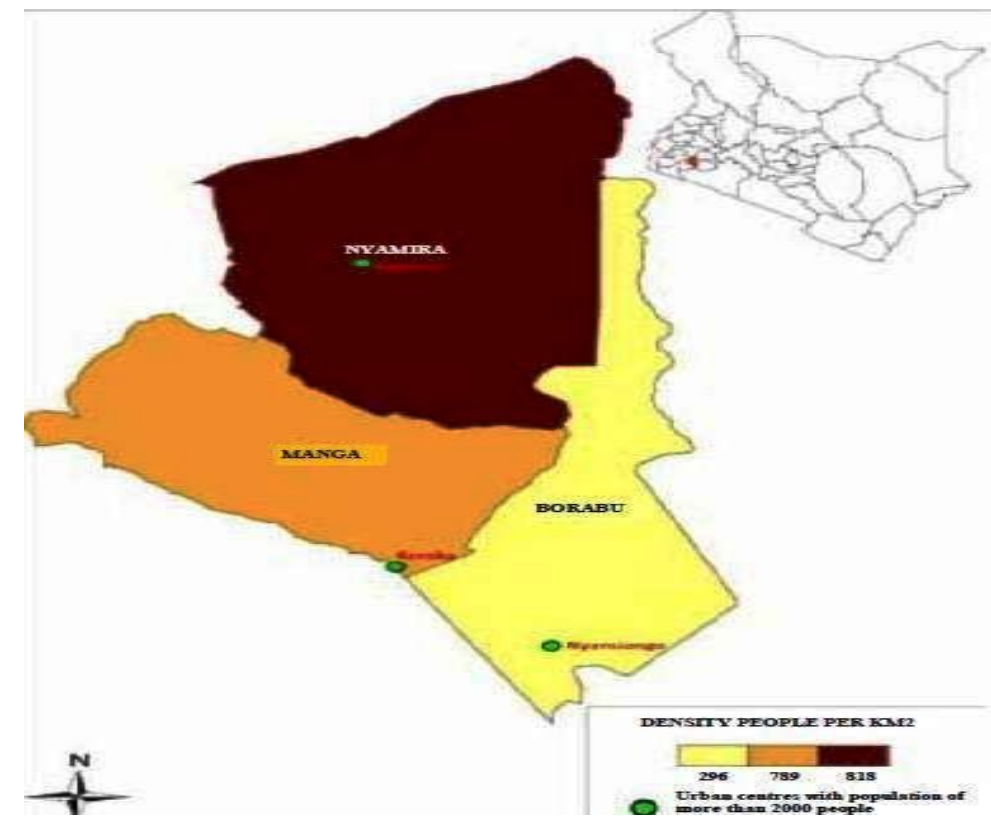

Figure 2.1 Map of Borabu sub County; Adopted from County commissioner office; Nyamira

\section{County, scale not shown}

\subsection{Data collection}

At onset of beans flowering, the number of bees visiting flowers was observed using a pair of binoculars at each site in the bean farm. The foraging bees species in the sampling plots was observed and captured along $1 \mathrm{~km}$ belt transect using a sweep net for 20 minutes. Some 10 minutes were taken after each collection to pin the bee species in boxes that were later transferred to storage drawers which were treated with naphthalene to protect the specimen from pest invasion and destruction. The common bean variety in the area is Mwezimoja which takes 90 days to mature and planted at a spacing of $50 \mathrm{~cm} \mathrm{x} 10 \mathrm{~cm}$. 
Also nine pan traps of different colours which are conspicuous such as pink, red, blue, yellow and white were laid at random points per plot within $100 \mathrm{~m}$ plot in the bean field to trap any pollinator that may not be collected by sweep nets. Every pan trap contained $200 \mathrm{ml}$ of water and $4 \mathrm{ml}$ of odourless detergent. All the bees trapped were counted and transferred to transparent containers using a pair of forceps for later identification and determination of diversity. During observation period, bees were differentiated by colour, size and some bees were identified up to genus level. The behaviour of bees in relation to time of visiting the flowers was noted and recorded in order to separate the mere floral visitors and the pollinators.

Observation of pollinators was from $07.30 \mathrm{am}$ to $12.30 \mathrm{pm}$. This was simultaneously done in the 3 study plots at the interval of 10 minutes in each sample plot with similar conditions to avoid variations [5]. The visitation rate of bees was observed by recording individual flower visitors and number of flowers in the sampled bean plots. Time taken for the bee flower visitors in contact with antherstigma relationship was recorded. A ten minute observation period was set to record the number of flower visitors per plot during the flowering period of beans.

\subsection{Data Analysis}

Diversity was computed using Shannon diversity index. Species abundance accumulation curves were used to compute abundance.

\subsection{Results}

\subsection{Abundance and diversity of bee flower visitors}

\subsubsection{Abundance of bee flower visitors}

Nine bee species from four genera belonging to two families were collected from the farms studied (Table 1). Apidae was the most abundant family with six bee species. There were five un- identified bee species; three from Apidae family and two from Megachilidae family. A total of 992 bee specimens from 2 families and 9 species were collected from the three study farms. The distribution of total bee specimens collected; 850 were A. mellifera, 77 were Melipona sp. 1 and 52 represented X. Calens. X. flavorufa were 2 and Xylocopa. sp. 1 was only 1 while Xylocopa sp. 2 were 7, Xylocopa $s p .3$ was also 1and Megachilida sp. 1 was only 1 bee species collected respectively (Table 1).

Table 1: Bee family, genera and species names

\begin{tabular}{|c|c|c|c|c|c|}
\hline & Family & Genus & Species & $\begin{array}{l}\text { No. of } \\
\text { individuals }\end{array}$ & Abundance( $\%)$ \\
\hline \multirow[t]{7}{*}{1} & \multirow[t]{7}{*}{ Apidae } & Apis & Mellifera & 850 & 85.7 \\
\hline & & \multirow[t]{5}{*}{ Xylocopa } & Calens & 52 & 5.2 \\
\hline & & & Flavorufa & 2 & 0.2 \\
\hline & & & $S p .1$ & 1 & 0.1 \\
\hline & & & Sp. 2 & 7 & 0.7 \\
\hline & & & Sp. 3 & 1 & 0.1 \\
\hline & & Melipona & Sp. 1 & 77 & 7.8 \\
\hline 2 & Megachilidae & Megachilida & Sp. 1 & 1 & 0.1 \\
\hline
\end{tabular}

In terms of abundance out of the total bee specimens collected, $85.7 \%$ were $A$. mellifera, $7.8 \%$ were Melipona sp. 1 and 5.2\% represented X. Calens. X. flavorufa was $0.2 \%$ and $X . s p .2$ had $0.7 \%$ of the total bee specimens collected while $X . s p .1, X . s p .3$ and $M . s p .1$ had $0.1 \%$ of the total bee species collected respectively (Figure 1). 


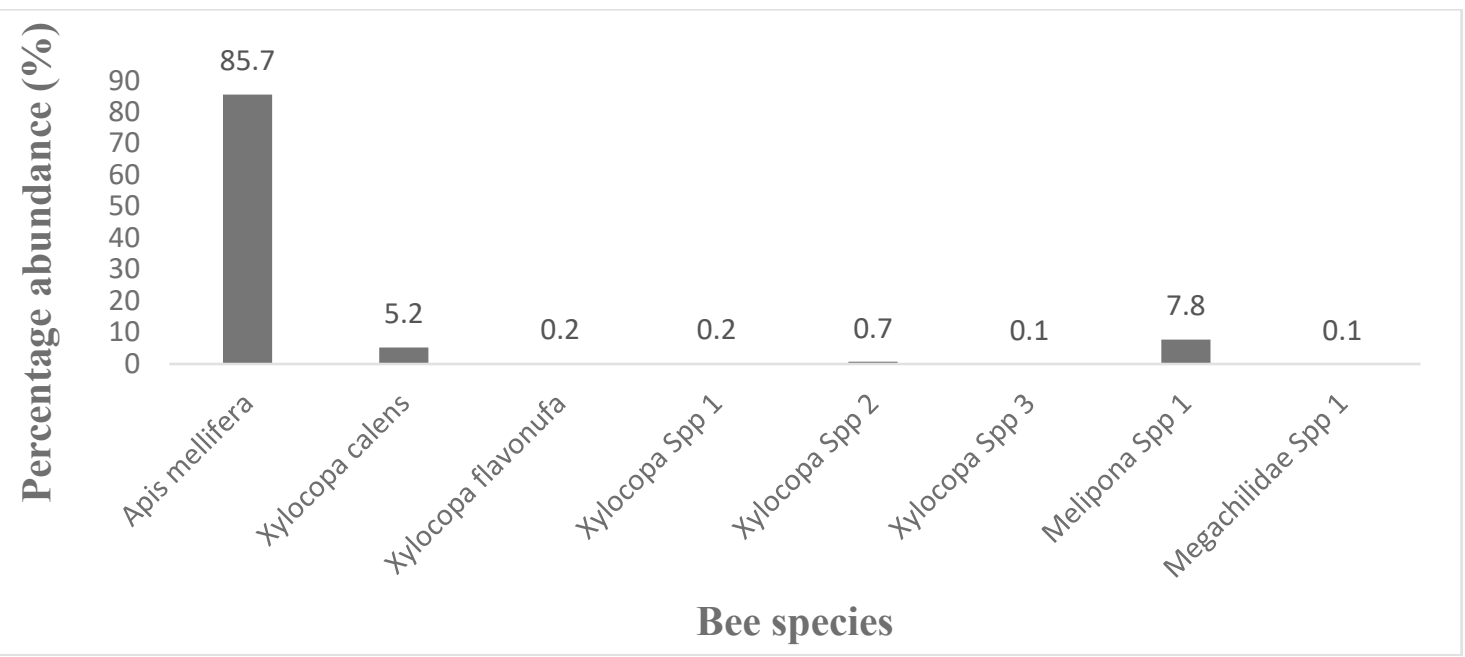

Figure 1: Percentage abundance of bee species collected

\subsubsection{Diversity of bee flower visitors}

Bee species diversity index was computed using Shannon index;

$H^{\prime}=-\sum \mathrm{p}_{i}\left(\ln \mathrm{p}_{i}\right)$

Where, $H^{\prime}=$ diversity, $\sum=$ Summation, $\mathrm{p}_{i}=\mathrm{N}_{i} \mathrm{~N}_{\text {total }}$, $\mathrm{ln}=$ natural logarithim, $\mathrm{N}_{i}=$ number of individuals of species $i$ and $\mathrm{N}_{\text {total }}=$ Total number of individuals in all species

The data on the bee diversity in different times of day was used to compute the Shannon-Wiener Diversity Index. The findings of the analysis are illustrated in Table 2.

Table 2: Diversity index of bee species visiting the bean flowers at different times of the day

\begin{tabular}{|c|c|c|c|c|c|c|c|c|c|c|c|}
\hline & & \multicolumn{10}{|c|}{ Time in the day } \\
\hline & & \multicolumn{2}{|c|}{ 7.00-8.00 } & \multicolumn{2}{|c|}{ 8.00-9.00 } & \multicolumn{2}{|c|}{ 9.00-10.00 } & \multicolumn{2}{|c|}{ 10.00-11.00 } & \multicolumn{2}{|c|}{$11.00-12.00$} \\
\hline \multicolumn{2}{|c|}{ Pollinator bee } & $\mathrm{Ni}$ & $\begin{array}{l}-(\mathrm{pi} * \\
\ln \mathrm{pi})\end{array}$ & $\mathrm{Ni}$ & $\begin{array}{l}-(\mathrm{pi} * \\
\ln \mathrm{pi})\end{array}$ & $\mathrm{Ni}$ & $\begin{array}{l}-(\mathrm{pi} * \\
\operatorname{lnpi})\end{array}$ & $\mathrm{Ni}$ & $\begin{array}{l}-(\mathrm{pi} * \\
\operatorname{lnpi})\end{array}$ & $\mathrm{Ni}$ & $\begin{array}{l}-(\mathrm{pi} * \\
\operatorname{lnpi})\end{array}$ \\
\hline 1 & \multirow{2}{*}{$\begin{array}{l}\text { Apis mellifera } \\
\text { Xylocopa } \\
\text { Calens }\end{array}$} & 77 & -0.130 & 264 & -0.125 & 203 & -0.153 & 81 & -0.201 & 225 & -0.089 \\
\hline 2 & & 2 & -0.078 & 27 & -0.215 & 14 & -0.163 & - & - & 9 & -0.120 \\
\hline 3 & $\begin{array}{l}\text { Xylocopa } \\
\text { Flavorufa }\end{array}$ & - & - & - & - & 2 & -0.039 & - & - & - & - \\
\hline 4 & Xylocopa Sp.1 & - & - & - & - & 1 & -0.023 & - & - & - & - \\
\hline 5 & Xylocopa Sp. 2 & - & - & - & - & 2 & -0.039 & 1 & -0.066 & 4 & -0.066 \\
\hline 6 & Xylocopa Sp. 3 & 1 & -0.050 & - & - & 1 & -0.023 & - & - & - & - \\
\hline 7 & Melipona Sp. 1 & 10 & -0.050 & 14 & -0.140 & 21 & -0.021 & 23 & -0.333 & 9 & 0.120 \\
\hline 8 & Megachilida Sp. 1 & - & - & - & - & - & - & - & - & 1 & -0.022 \\
\hline \multicolumn{2}{|c|}{ TOTAL } & 90 & $\begin{array}{l}\boldsymbol{H}^{\prime} \\
=0.31\end{array}$ & 305 & $\begin{array}{l}\boldsymbol{H}^{\prime} \\
=0.35\end{array}$ & 244 & $\begin{array}{l}\boldsymbol{H}^{\prime} \\
=0.46\end{array}$ & 105 & $\begin{array}{l}\boldsymbol{H}^{\prime} \\
=0.60\end{array}$ & 248 & $\boldsymbol{H}^{\prime}=0.42$ \\
\hline
\end{tabular}

The pollinator diversity was low during early morning hours, 7.00am-8.00am $\left(H^{\prime}=0.31\right)$, 8.00am9.00am recorded $H^{\prime}$ of 0.35 and 9.00am-10.00am had diversity index of 0.46 respectively. The peak activity was recorded at $10.00 \mathrm{am}-11.00 \mathrm{am}$ with diversity index of 0.60 decreased consecutively in the day, 11.00am-12.00am $\left(H^{\prime}=0.42\right)$. However, the peak abundance of flower visitors was during morning hours tending to noon. The findings of the analysis are illustrated in Figure 2. 


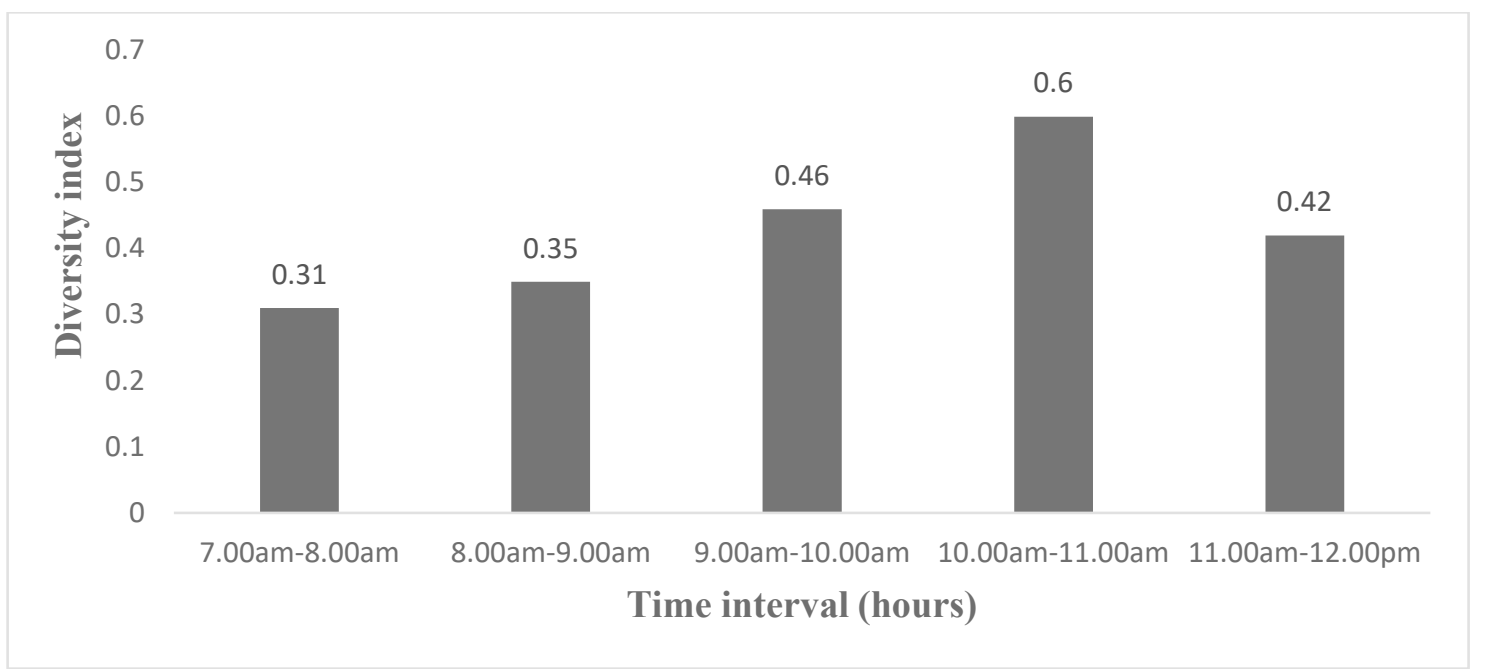

Figure 2: Diversity index of individual bee species

The overall diversity index of bee species collected from all the farms was also computed and the results are as presented in Table 3 .

Table 3: Overall diversity index of bee species collected from the study farms

\begin{tabular}{|c|c|c|c|c|c|}
\hline & Bee species & $\begin{array}{l}\text { No. of } \\
\text { Individuals }\end{array}$ & $\begin{array}{l}\text { pi }= \\
\text { Sample/sum }\end{array}$ & $\ln (\mathbf{p} i)$ & $P i * \ln (p i)$ \\
\hline 1 & Apis mellifera & 850 & 0.857 & -0.154 & -0.132 \\
\hline 2 & Xylocopa Calens & 52 & 0.052 & -2.957 & -0.154 \\
\hline 3 & Xylocopa Flavorufa & 2 & 0.002 & -6.215 & -0.012 \\
\hline 4 & Xylocopa Sp.1 & 1 & 0.001 & -6.908 & -0.007 \\
\hline 5 & Xylocopa Sp. 2 & 7 & 0.007 & -4.962 & -0.035 \\
\hline 6 & Xylocopa Sp. 3 & 1 & 0.001 & -6.908 & -0.007 \\
\hline 7 & Melipona Sp. 1 & 77 & 0.078 & -2.551 & -0.199 \\
\hline 8 & Megachilida Sp. 1 & 1 & 0.001 & -6.908 & -0.007 \\
\hline \multicolumn{3}{|c|}{ SUM $=992$} & & \multicolumn{2}{|c|}{ TOTAL $=-\mathbf{0 . 5 5 3}$} \\
\hline
\end{tabular}

Diversity index $H^{\prime}$; summation of $i^{*} \ln (\mathrm{p} i)$ of each bee species and therefore; $H^{\prime}=0.553$

\subsection{Discussion}

\subsection{Abundance and diversity of bee pollinators}

\subsubsection{Abundance of bee pollinators}

Nine bee species from four genera belonging to two families were collected from the farms studied. However, some bee species were identified only up to morpho-species level since bee diversity in the tropical regions is poorly studied and documented. Bees are among the most poorly studied insect groups in East Africa following also lack of rich bee collections and many bee taxonomists.

Most bee collections in East African Museums are characterized by misidentified or taxonomic collections that are not up to date as noted by [4]. Apis followed by Xylocopa recorded the highest bee abundance. The individuals of $A$. mellifera were more compared to other bee species, even though this species does not pollinate beans effectively than other bees. The high abundance of this bee species is of great significance in enhancing the pollinator force of the effective pollinator as observed by [9].

The collective role of a species rich bee community is very important for pollination success [11]. The number of individuals of A. mellifera was higher than those of other bee species and kept dominating in each sampled farm compared to other bee species. The number is especially of importance in improving the pollinator force of the effective pollinator as observed by [8].

Apis was observed in all sampled farms because it was the dominant bee in the area and the social bees visiting bees were more abundant though less diverse than solitary bees. According to [11], $A$. 
mellifera is a social bee and sociality is often central since social bees can communicate the presence of resources to their colony and recruit in large numbers to mass flowering crops like coffee. $A$. mellifera is aggressive in nature and takes advantage of intense nectar flow associated with coffee flowering [22]. It can also colonise and persist in many different habitat types, nest under a variety of conditions and forage on a great diversity of both native and alien flowers [1]. These findings are in agreement with those of related studies conducted by [11], that also indicated that A. mellifera and solitary bees are the main pollinators of C. arabica. In a related study done in Mexico by [22], they found out that $A$. mellifera was the most abundant bee species accounting for more than $80 \%$ of total pollinator assemblages. These results are also in agreement with studies on coffee pollinators from tropical America which also found that honey bees are the most abundant pollinators on coffee flowers [19].

\subsubsection{Diversity of the bee pollinators}

This study realized that a high diversity of bees that visit bean flowers. The foraging activity of bee visitors was highest between 10.00am and 11.00am with a diversity index of 0.60 . Similar observations were made by [23], who reported peak activity of Xylocopa olivacea on bean flowers flowers between $10.00 \mathrm{am}$ and $13.00 \mathrm{pm}$. They affirmed that the peak activity correlated with the highest nector availability period in the flowers. With broad bean [24] observed that bees visiting extra floral nectaries tended to be most numerous at midday, while those visiting flowers, especially for pollen, will be most numerous past midday. These findings are also in line with those obtained by [20] who found out that bee foraging activity kept on increasing from morning hours to afternoon hours. They recorded a diversity index of 1.01 between $6.00 \mathrm{am}-10.00 \mathrm{am}$ and 1.27 respectively.

Individuals belonging to nine bee species were observed visiting bean flowers in the Nyansiongo farmland. However, 17 bee species were recorded by [4] visiting flowers of non-crop plants belonging to Fabaceae family. Additionally, Gikungu (ibid.) found more than 200 species of bees in the forest and in the more open farmland. According to Greenleaf and [12], diversity and not abundance of wild bee populations is what determines pollination success. These results also agrees with those obtained by [15] on French beans at the North-Eastern slopes of Mt Kenya which recorded bees in five families, five genera and eight species. Similarly, these findings are in line with those of [10] and [2] in Cameroon whereby each recorded seventeen species of bees on flowers of $P$. vulgaris crops.

\subsection{Conclusion}

The findings of this study have revealed that diversity and abundance of bee flower visitors of beans in Borabu Sub-County, Western Kenya was high and these flower visitors are important in bean crop production and therefore, there is a need to conserve the populations of non-Apis bees, especially, Xylocopa and Megachilida in order to enhance bean production.

\section{Conflict of Interest}

"The author(s) declare(s) that there is no conflict of interest."

There was no role of the funding sponsors in the design of the study; in the collection, analyses or interpretation of data; in the writing of the manuscript, or in the decision to publish the results.

\section{Acknowledgement}

The author would like to acknowledge the support and advice given by the study supervisors, the zoology department of Jomo Kenyatta University of Agriculture and Technology, the farm managers, the librarians at the National museum of Kenya. 


\section{References}

[1] N.P. Chacoff and M.A. Aizen (2006). Edge effects on flower-visiting insects in grapefruit plantations bordering premontane subtropical forest. J. Appl Ecol 43:18-27

[2] D. Chantal and T.F. Fernand-Nestor (2013). Foraging and pollination behavior of Apis mellifera adansonii L. on Phaseolus vulgaris (Fabaceae), Cameroon. International Research Journal of Plant Science (ISSN: 2141-5447), vol. 4(2) pp. 45-54, february, 2013.

[3] M.W. Gikungu (2018). Studies on bee population and some aspects of their foraging behaviour In Mt. Kenya forest, MSc. Thesis, University of Nairobi.

[4] M. W. Gikungu (2006). Bee diversity and some aspects of their ecological interactions with plants in a succession tropical community. Dissertation, University of Bonn.Gill, R.A. (1991). The value of honeybee pollination to society. Acta Hort. 288: 62-68.

[5] M. Gikungu, K. et al., (2018) Distance Effects on Diversity and Abundance of the Flower Visitors of Ocimum kilimandscharicum in the Kakamega Forest Ecosystem. Hindawi International Journal of Biodiversity Volume 2018, Article ID 7635631, 7 pageshttps: //doi.org/10.1155/ 2018/7635631.

[6] M. Hagen, M. Kraemer, M. Kasina (2009a). Bee pollination enhances crop yield and crop quality in Kakamega, Western Kenya. E. Afr. Agric. For J. 75:1-11.

[7] KNBS (Kenya National Bureau of Statistics), (2019). Kenya population and Housing Census.

[8] J.M. Kasina (2007) Bee pollinators and economic importance of pollination in crop Production: Case of Kakamega, Western Kenya. Bonn. Univ., Diss., Zugl.

[9] J.M. Kasina, M. Kraemer, C. Martius and D. Wittmann (2009c). Diversity and activity density of bees visiting crop flowers in Kakamega, western Kenya. Journal of Apicultural Research 48:134-139.

[10] B.M.T. Kingha, F.N.T. Fohouo, A. Ngakou and D. Brückner (2012). Foraging and pollination activities of Xylocopa olivacea (Hymenoptera, Apidae) on Phaseolus vulgaris (Fabaceae) flowers at Dang (Ngaoundere-Cameroon). Journal of Agricultural Extension and Rural Development 4(6):330-339

[11] A.M. Klein et al., (2008). Advances in Pollination ecology from tropical plantation crops. Ecology 89(4): 935-943.

[12] C. Kremen, N.M. Williams, J.P. Bugg \& W. Thorp (2012). The area requirements of an ecosystem service: crop pollination by native bee communities in California. Ecology Letters, 7:1109-1119. Blackwell Publishing Ltd / CNRS.

[13] S. Kluser and P. Peduzzi (2007). Global Pollinator Decline: A Literature Review. NEP/GRIDEurope Am. 29.

[14] A. Kosior et al., (2007). The decline of the bumble bees and cuckoo bees (Hymenoptera: Apidae: Bombini) of Western and Central Europe Oryx, 41(1): 79-88

[15] R. Masiga et al., (2014). Do French beans (Phaseolus vulgaris L.) grown in proximity to Mt Kenya forest in Kenya experience pollination deficit? Journal of Pollination Ecology, 14(24), 2014, pp. 255-260

[16] Munyuli, T. M. B. (2010). Pollinator biodiversity and economics of pollination Services in Uganda. PhD. dissertation, Makerere University, Kampala, Uganda. P. 451

[17] National Research Council (2007). Status of Pollinators in North America. National Academies Press, Washington, DC. 
[18] Potts, (2010). Ecological and life-history traits predict bee species responses to environmental disturbances. Biological Conservation 143: 2280-2291

[19] D.W. Roubik (2009). "The value of bees to the coffee harvest." Nature 417:708.

[20] B.P. Shambhu, Belavadi, V.V. (2013). Flower Visitors of Field Bean Lablab Purpureus (L.) Sweet and Their Role In Pollination And Pod Set. Masters' Thesis; Agricultural Entomology BANGALORE.

[21] C.E. Shannon, W. Weiner (1949) The mathematical theory of communication. Urbana University of Illinois Press.

[22] C.H. Vergara \& E.I. Badano (2008). Pollinator diversity increases fruit production in Mexican coffee plantations: The importance of rustic management systems. Agriculture, Ecosystems and Environment (AGEE) xxx(2008) xxx-xxx.

[23] M.L. Kasper, A.F. Reeson, D.A. Mackay and A.D. Austin (2008). Environmental factors influencing daily foraging activity of Vespula germanica (Hymenoptera: Vespidae) in Mediterranean Australia. Insect Soc., 55: 288-296.

[24] Barbara-Herren and Gemmill, (2008). Tools for conservation and use of pollinator services: Initial Survey of Good Pollination Practices. Food \& Agriculture Organisation, Rome. Pp.133. 